\title{
ANALYSIS AND DESIGN OF MOBILE WEB-BASED MENU E-ORDER SYSTEMS USING THE PIECES METHOD (CASE STUDY: CAFÉ 50/50 COFFEE)
}

\author{
Nabilah Ananda Pratiwi ${ }^{1)}$, Agung Triayudi ${ }^{*}$ ), Endah Tri Esti Handayani ${ }^{3)}$ \\ Sistem Informasi, Fakultas Teknologi Komunikasi dan Informatika \\ Universitas Nasional \\ 2018nabilah@student.unas.ac.id ${ }^{1}$, agungtriayudi@civitas.unas.ac.id ${ }^{2 *}$, endahtriesti@civitas.unas.ac.id ${ }^{3)}$
}

(*) Corresponding Author

\begin{abstract}
Abstrak
Kafe sebagai tempat untuk melepas penat maupun bercengkerama dan pengunjung dapat melakukan pemesanan menu yang tersedia. Pada umumnya sebuah kafe sering mengalami kesulitan dalam melayani pelanggan, terutama untuk fasilitas pemesanan menu. Hal ini juga dialami oleh Kafe 50/50 Coffee yang masih melakukan pemesanan menu secara manual. Berdasarkan permasalahan tersebut, dirancang sebuah sistem e-order menu aplikasi mobile berbasis web. Penelitian ini bertujuan untuk menghasilkan sistem pemesanan mobile web yang kemudian dianalisis dengan indikator PIECES untuk mendapatkan nilai kepuasan dari pengguna. Perancangan sistem menggunakan metode pengembangan System Development Life Cycle (SDLC) model waterfall kemudian dilakukan analisis tingkat kepuasan pengguna dengan metode PIECES. Pengujian sistem menggunakan usability testing dengan metode USE Questionnaire. Implementasi sistem dibuat dengan bantuan framework CodeIgniter dan menggunakan bahasa pemrograman PHP. Hasil penelitian berupa sistem e-order menu pada kafe 50/50 Coffee dengan kesimpulan dari hasil analisis bahwa pengguna sistem e-order sudah merasa "PUAS".
\end{abstract}

Kata kunci: Sistem E-Order, Mobile web, Metode Waterfall, PIECES Framework, USE Questionnaire

\begin{abstract}
Café as a place to relax or chatter where visitors can order the menu available. In general, a café often has difficulty in serving customers, especially for menu ordering facilities. This is also experienced by café 50/50 Coffee which still makes menu reservations manually. Based on these problems, a system of e-order menus of web-based mobile applications is designed. The study aims to produce a mobile web ordering system that is then analyzed with the PIECES indicator to determine the level of user satisfaction. Design of this system using the waterfall model System Development Life Cycle (SDLC) development method and then analyzed the level of user satisfaction with the PIECES method. System testing uses usability testing with the USE Questionnaire method. System implementations are created with the help of the CodeIgniter framework and use the PHP programming language. The results of the study in the form of a menu e-order system at the 50/50 Coffee café with the conclusion of the analysis that the users of the e-order system were "SATISFIED".
\end{abstract}

Keywords: E-Order system, Mobile web, Waterfall method, PIECES Framework, USE Questionnaire

\section{INTRODUCTION}

Information systems and technology are increasingly evolving so as to change the way and lifestyle also facilitate people in daily activities. Technology is growing rapidly, so most people prefer to use technology in their activities. One of the example is internet and websites. Website can help in terms of promoting a business, making it easier for customers to order menus and in order to win the competition (Marudut \& Siregar, 2018).
Café as a place to relieve exhaustion or chatter where visitors can order the menu available (Bastian, 2020). In addition to the menu offered, restaurant and café services in providing satisfaction to customers are also very influential on competition in the culinary business (Triayudi \& Rodhi, 2018). Café 50/50 Coffee is one of the businesses in the culinary sector. This café is located at Jalan Nusantara No. 50, Depok city, West Java. During this time the booking facility is still done manually, i.e. visitors must do it directly 
through the cashier so that it can cause queues. This is less effective, especially during the COVID-19 pandemic that is currently ongoing almost all over the world, including in Indonesia. Therefore, there is a rule that requires people to do social distancing to limit social activities in order to avoid physical contact and crowds (Suherman et al., 2021). Apart from that, there are other problems i.e. to find out information related to the menu in more detail or information about the availability of tables, visitors must directly come to the café.

The menu e-order system at the café 50/50 Coffee can make it easier for visitors to make table reservations and menu reservations more effectively and efficiently. Then an analysis of user satisfaction levels with the PIECES method is carried out in order to get an evaluation of a system that has been created before (Julian, Triayudi, \& Benrahman, 2021). As for the analysis conducted so that the e-order system can meet the qualifications in the PIECES framework (Tjiptabudi, 2017). This study aims to produce a mobile web ordering system which is then analyzed with the PIECES method to find out the level of user satisfaction. With the food and beverage menu e-order system, it is expected to be useful to help visitors in ordering online.

Some previous research related to the development of menu e-order systems, in the study (Fonggo, Beng, \& Arisandi, 2020) the ordering system using the SDLC method with the waterfall model. Program creation uses HTML and PHP also MySQL as database storage. The results of the study in the form of a web-based payment and booking system implemented in the canteen.

The research (Manikam \& Ardiyansah, 2019) conducted a system design at Bebek Goreng Haji Yogi Restaurant that utilizes the PIECES method for problem analysis. System design uses balsamiq software with PHP programming language. The result of the study is in the form of the design of an e-order system.

In research (Dhiman, 2021) online food ordering management system used in the culinary field. Website implementations are performed using PHP, HTML, CSS and datasets stored in the PHPMyAdmin SQL database. The result is a website-based online food ordering system that will be applied in small restaurants and locations such as college canteens, etc.

Research (Riswanda \& Priandika, 2021) about ordering system on the Donnys store uses PHP programming languages and MySQL databases also designed using UML (Unified Modeling Language). System development utilizes waterfall methods and analyzes system needs with the
PIECES method. The results of the study are in the form of items order management applications.

In the study (Dzulfiqar, 2019) apply PIECES analysis to the current system. By using UML as a system design. The results of this study are in the form of an application that makes it easier for customers to order food on Bu Sri's Food Stalls.

Based on these studies, the authors built a food and beverage menu e-order system to be applied to café 50/50 Coffee. System design applies the system development life cycle (SDLC) waterfall model method as well as the PIECES framework method to determine the level of user satisfaction. As for testing using usability testing with the USE Questionnaire method.

\section{RESEARCH METHODS}

\section{Types of Research}

The type of research used by the authors is qualitative descriptive using data collection methods namely observation, interviews, and literature studies.

\section{Time and Place of Research}

The study was conducted in October 2021 at the café 50/50 Coffee.

\section{Research Target / Subject}

The study focused on issues related to the ordering system at café 50/50 Coffee.

\section{Data Collection Methods}

The data was collected with observations related to the problems that occurred in the café $50 / 50$ Coffee and the collection of references obtained from previous studies to get an idea of the needs of the system to be made. Questionnaires were also distributed to system users and interviews with the owners/employees of the café in order to produce accurate data.

\section{System Development Methods}

SDLC is a life cycle in software development. SDLC helps developers improve the quality of the software produced. SDLC emphasizes the needs of users and with a structured approach to building or developing new systems (Rahayu, Susanto, \& Suwarjono, 2020). Waterfall method is included in the system development model by focusing on sequenced and systematic stages. Waterfall method stages (Muhammad Robith Adani, 2020):

1. Requirement

The first stage is to analyze the needs of the system to be built. Information is obtained from observations, analysis with PIECES Framework 
indicators, and interviews with the related café, as well as conducting literature studies.

2. Design

The next stage is the creation of a system design which is the process by which functional analysis of the system is applied to the Unified Modelling Language (UML).

3. Implementation

The implementation stages of program code use Visual Studio Code tools as text editors with the help of the CodeIgniter framework, also use the PHP programming language. In addition, the system is designed with some supporting software such as XAMPP.

4. Integration \& Testing

This stage aims to know the suitability of the system with the design, functionality of the system, and to prevent bugs or errors in the system. Testing is done by applying usability testing method USE Questionnaire.

5. Operation \& Maintenance

After testing the system, then proceed to the system usage stage by the user (user). At this stage, the developer can make improvements if an error is found in the system that has been used by the user.

\section{Methods of Analysis}

The analysis method used is PIECES Framework which is a method to identify in order to solve problems that occur in the system against indicators Performance, Information, Economy, Control, Efficiency, and Service (Salwa Husna, Fadli, \& Hajar, 2018).

Table 1. Analysis of Problem Identification with THE PIECES Method

\begin{tabular}{|c|c|c|}
\hline $\begin{array}{l}\text { PIECES } \\
\text { Indicators }\end{array}$ & Old System & New System \\
\hline $\begin{array}{c}\text { Performanc } \\
\text { e }\end{array}$ & $\begin{array}{l}\text { Menu ordering } \\
\text { is still done } \\
\text { directly } \\
\text { through the } \\
\text { cashier. } \\
\text { Ordering takes } \\
\text { a long time in } \\
\text { choosing a } \\
\text { menu, so it can } \\
\text { cause queues. }\end{array}$ & $\begin{array}{l}\text { Menu } \\
\text { reservations } \\
\text { can be made } \\
\text { via } \\
\text { smartphone } \\
\text { which can be } \\
\text { easily accessed } \\
\text { by users } \\
\text { before coming } \\
\text { to the café. }\end{array}$ \\
\hline Information & $\begin{array}{l}\text { Customers } \\
\text { need to come } \\
\text { directly to get } \\
\text { more } \\
\text { information }\end{array}$ & $\begin{array}{l}\text { Information } \\
\text { related to } \\
\text { order data and } \\
\text { menu details } \\
\text { also table }\end{array}$ \\
\hline & $\begin{array}{l}\text { related to } \\
\text { detailed order } \\
\text { and menu and }\end{array}$ & $\begin{array}{l}\text { availability is } \\
\text { faster and } \\
\text { easier to get }\end{array}$ \\
\hline
\end{tabular}

\begin{tabular}{|c|c|c|}
\hline $\begin{array}{l}\text { PIECES } \\
\text { Indicators }\end{array}$ & Old System & New System \\
\hline & $\begin{array}{l}\text { also } \\
\text { information } \\
\text { about table } \\
\text { availability. }\end{array}$ & $\begin{array}{lr}\text { just } & \text { by } \\
\text { accessing } & \text { the } \\
\text { web. } & \end{array}$ \\
\hline Economy & $\begin{array}{l}\text { Errors may } \\
\text { occur } \\
\text { regarding } \\
\text { orders and } \\
\text { total payments } \\
\text { generated. } \\
\text { Menu ordering } \\
\text { activities } \\
\text { require more } \\
\text { manpower. }\end{array}$ & $\begin{array}{l}\text { The order } \\
\text { process, order } \\
\text { details and } \\
\text { total payment } \\
\text { are processed } \\
\text { automatically } \\
\text { through the } \\
\text { system. }\end{array}$ \\
\hline Control & $\begin{array}{l}\text { Data can be } \\
\text { accessed by } \\
\text { anyone, so } \\
\text { security is less } \\
\text { maintained. } \\
\text { The process of } \\
\text { managing data } \\
\text { that is still } \\
\text { manual takes a } \\
\text { long time. }\end{array}$ & $\begin{array}{l}\text { Existing data } \\
\text { can only be } \\
\text { accessed by } \\
\text { the related } \\
\text { admin. } \\
\text { The data } \\
\text { management } \\
\text { process takes } \\
\text { place quickly. }\end{array}$ \\
\hline Efficiency & $\begin{array}{l}\text { The process of } \\
\text { recapting data } \\
\text { can takes a long } \\
\text { time because } \\
\text { recording is } \\
\text { still done } \\
\text { manually. }\end{array}$ & $\begin{array}{l}\text { The time } \\
\text { required for } \\
\text { the recap } \\
\text { process is only } \\
\text { a little because } \\
\text { admins can } \\
\text { directly access } \\
\text { it on the } \\
\text { system. }\end{array}$ \\
\hline Service & $\begin{array}{l}\text { The exchange } \\
\text { of information } \\
\text { that occurs is } \\
\text { still done } \\
\text { directly. }\end{array}$ & $\begin{array}{l}\text { The exchange } \\
\text { of information } \\
\text { is more detail } \\
\text { and fast } \\
\text { because it is } \\
\text { easily } \\
\text { accessible } \\
\text { online. }\end{array}$ \\
\hline
\end{tabular}

Data analysis was conducted from the questionnaires distribution to find out the level of user satisfaction with the e-order system involving 6 PIECES indicators. Respondents were involved as many as 20 people according to the range of café $50 / 50$ Coffee visitors every day. The study used the satisfaction level likert scale listed in table 2 .

Table 2. Satisfaction Level Likert Scale

\begin{tabular}{cc}
\hline Answer Options & Score \\
\hline Strongly Agree & 5 \\
Agree & 4 \\
Neutral & 3
\end{tabular}




\begin{tabular}{cc} 
Disagree & 2 \\
Strongly Disagree & 1 \\
\hline
\end{tabular}

Table 3 is the assessment characteristic for the PIECES Framework method (Ramadhani \& Kusuma, 2018).

Table 3. Level of Satisfaction

\begin{tabular}{cc}
\hline Categories & Value Range \\
\hline Very Dissatisfied & $1-1,79$ \\
Not Satisfied & $1,8-2,59$ \\
Quite Satisfied & $2,6-3,39$ \\
Satisfied & $3,4-4,91$ \\
Very Satisfied & $4,92-5$ \\
\hline
\end{tabular}

\section{Testing Methods}

The test used is the usability testing method USE Questionnaire, which consists of 4 aspects, namely usefulness, easy of use, easy of learning, and satisfaction (Retnoningsih \& Fauziah, 2019). The test on this study involved 20 respondents from a population that is the range of visitors at a café $50 / 50$ Coffee every day. This is based on Nielsen's theory that results with a large number of usability testing and with only 20 respondents will not be much different, so it will save more costs and time if the number of respondents is less (Setiyani, Syamsudin, Gintings, \& Arifin, 2020).

The test was conducted by distributing questionnaires by providing 5 alternative assessments using the likert scale as in table 2 . Then an average search is performed for each respondent's answer and performs interval calculations as in equation 1 .

Interval $(\mathrm{I})=\frac{100}{\text { Jumlah skor (Likert) }}$

Interval (I) $=\frac{100}{5}=20$

From the results of the interval can be categorized in the eligibility table contained in table 4.

Table 4. Eligibility Category

\begin{tabular}{cc}
\hline Eligibility Category & Score (\%) \\
\hline Very Useless & $<21$ \\
Not useful & $21-40$ \\
Quite Useful & $41-60$ \\
Useful & $61-80$ \\
Very Useful & $81-100$ \\
\hline
\end{tabular}

\section{RESULTS AND DISCUSSION}

\section{Requirements}

The café menu e-order system has 2 levels of users, namely visitors who want to order at the café and admin.

1. Café Visitors

Visitors can view the available menus, order menus, manage orders, receive confirmations and order details.

2. Admin

Admins who also act as cashiers can login, manage master data, monitor desks, manage orders, confirm arrivals and payments of visitors, print proof of payment, and perform logout.

\section{System Design}

a. System Menu Scheme Design

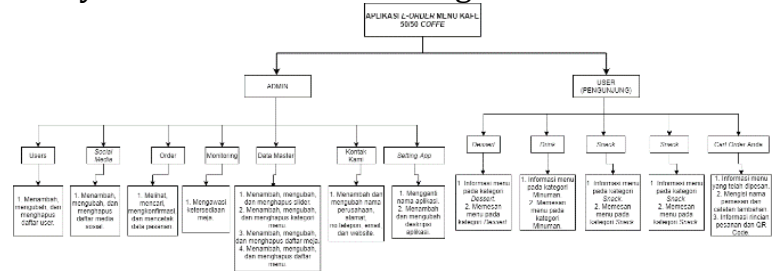

Figure 1. System Main Menu Scheme

In figure 1, it can be seen that the café 50/50 Coffee menu e-order system has many menu features that are divided into two parts of the interface, namely the user side as a visitor and the admin side. Both of these sections have interfaces, as well as different roles and menu features. The difference is that visitors can only access parts of the web interface. While admins can access, change, delete available data and set up a web interface.

b. Use Case Diagram

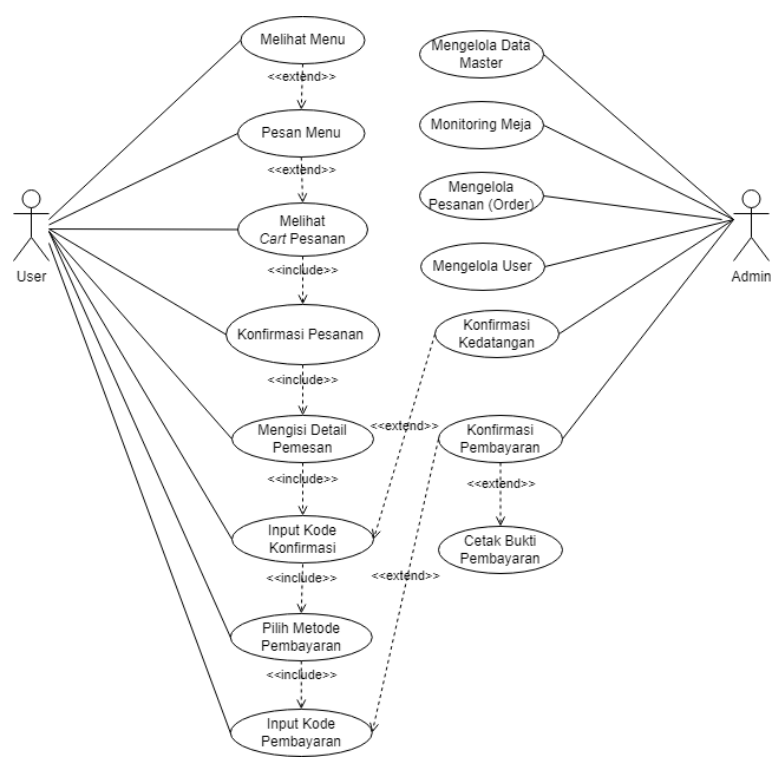

Figure 2. Use Case Diagram 
In figure 2 there is a use case diagram proposed as a depiction of the functionality of eorder system. There are two actors who interact with the system, namely admin and user. Such interactions are like viewing, ordering, inputting, confirming order data for user and processing data, order, and user for admin.

\section{c. Activity Diagram}

In figure 3 there is an activity diagram that contains the ordering activity in ordering through the e-order menu system. Starting from the booker who sees and selects the menu you want to order until the payment process.

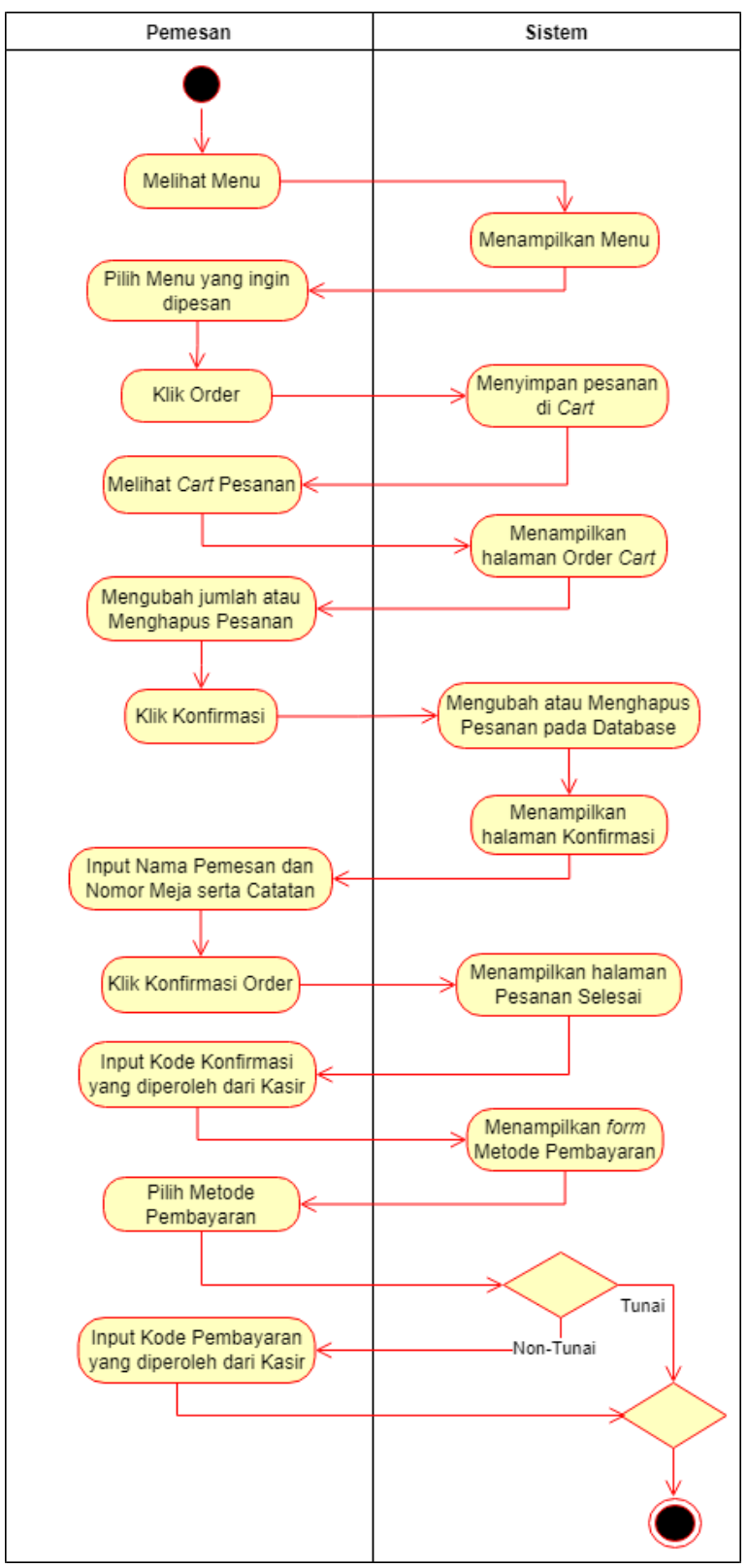

Figure 3. Activity Diagram

\section{System Interface Implementation}

1. Admin Page - Login Page View

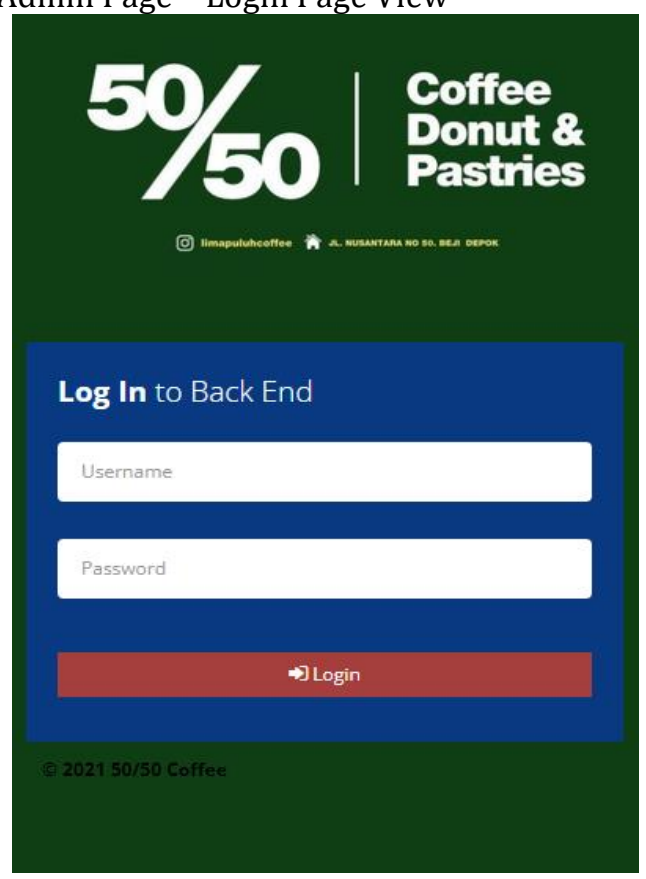

Figure 4. Login Page

In figure 4 displays the login page, where an admin needs to enter his username and password to be able to enter the application. Admins who have successfully logged in and entered the application, will go to the dashboard page.

2. Admin Page - Dashboard Page View 

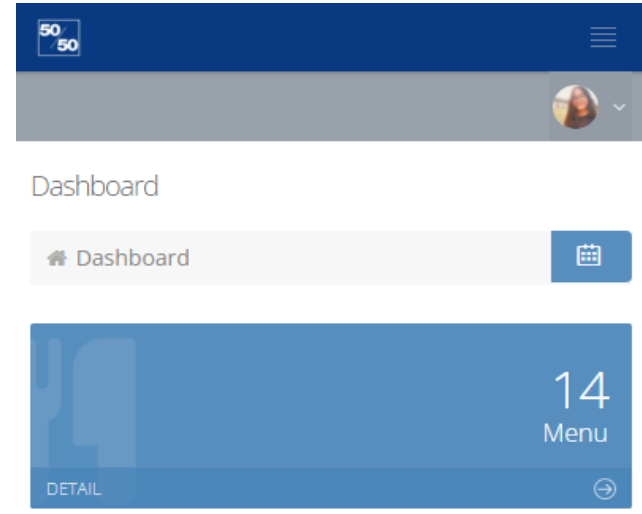

417,000 Income November 2021

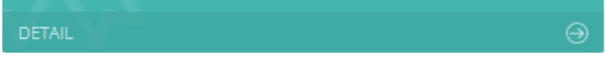

\section{$1,512,000$}

Figure 5. Dashboard Page

In figure 5 there is a dashboard page where admins can monitor the number of menus that are currently available, revenue per month and total overall revenue.

\section{User Page - Menu Details View}

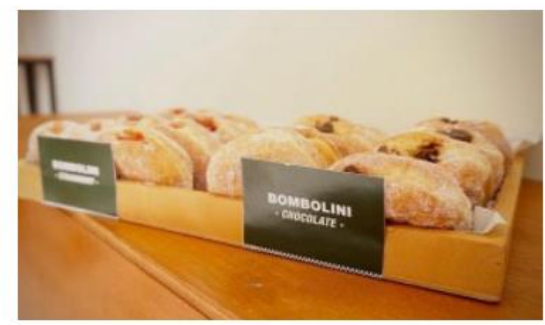

\section{Bombolini}

Rp. 8,000

Donat Yang Tidak Bolong Tengahnya Dengan Berbagai Variant Rasa

\section{略}

Figure 6. Menu Details Page

Figure 6 displays the menu details page listed photos, descriptions, length of creation and price as well as the number of menus that visitors want to order.
4. User Page - Order Menu View

$$
\text { Menu: }
$$

BOMBOLINI

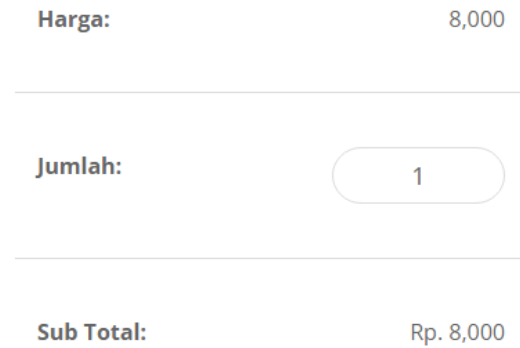

\section{iiil}

Figure 7. Order Menu Page

In figure 7 displays the order basket from the menu that the visitor has chosen to order. On this page visitors can still change the number and delete the order that has been selected.

\section{System Analysis}

a. Results of Calculation and Analysis of User Satisfaction Levels

The assessment of user satisfaction levels of the e-order menu system uses a likert scale such as table 2 based on questionnaires distributed to 20 respondents. The method used is PIECES with the formula of the average level of satisfaction (RK) of the system as in equation 2 .

$$
\mathrm{RK}=\frac{\text { Number of Questionnaire Scores }}{\text { Number of Questionnaires }}
$$

Here are the results of the questionnaire calculations of each PIECES indkator as in table 5.

Table 5. Results of Satisfaction Level of PIECES

\begin{tabular}{ccc}
\multicolumn{2}{c}{ Indicator } & \\
\hline PIECES & $\begin{array}{c}\text { Average } \\
\text { Indicators }\end{array}$ & Score \\
& $(\mathrm{RK})$ & \\
\hline Performance & 4,35 & SATISFIED \\
Information & 4,43 & SATISFIED \\
Economics & 4,27 & SATISFIED \\
Control & 4,33 & SATISFIED \\
Efficiency & 4,48 & SATISFIED \\
Service & 4,5 & SATISFIED \\
\hline Total & $\mathbf{4 , 3 9}$ & SATISFIED \\
\hline
\end{tabular}


The results of the calculation of average satisfaction (RK) users on the Performance indicator get a value of 4.35 then based on the level of satisfaction in table 3 can be categorized as SATISFIED. In the Information indicator gets a value of 4.43 then it can be categorized as SATISFIED. In the Economics indicator gets a value of 4.27 then the economic value indicator can be categorized as SATISFIED. In the Control indicator gets a value of 4.33 then it can be categorized as SATISFIED. In the Efficiency indicator gets 4.48 then it can be categorized as SATISFIED. On the Service indicator gets 4.5 then it can be categorized as SATISFIED. Based on these results, it can be concluded that users of the menu e-order system at café 50/50 Coffee are SATISFIED.

\section{System Testing}

a. Measurement of Usability with Use Questionnaire method

Testing was conducted by spreading questionnaires that adopted questions related to 4 aspects of the USE Questionnaire. Questionnaires were distributed to prospective users of the café $50 / 50$ Coffee e-order system as many as 20 respondents. Respondents accessed the e-order system and used it, then filled out a questionnaire by giving an assessment according to the likert scale in table 2 . The measurement of usability is obtained by calculating the percentage of answers from all respondents as in equation 3 . The number of observed scores was obtained by calculating the results of all respondents's answers to each aspect which was then multiplied by each score using the likert scale. The number of expected scores obtained from the highest value of the likert scale is multiplied by the number of respondents and then multiplied by the number of questions each aspect of usability.

PK $(\%)=\frac{\text { Observed score }}{\text { Expected score }} \times 100$

The results of usability measurements can be seen in table 6 , then obtained calculations and percentage eligibility (PK).

Table 6. Usability Aspect Measurement Results

\begin{tabular}{cccc}
\hline $\begin{array}{c}\text { Aspects of } \\
\text { Usability }\end{array}$ & $\begin{array}{c}\text { Respondent } \\
\text { Score }\end{array}$ & $\begin{array}{c}\text { Max } \\
\text { Score }\end{array}$ & $(\%)$ \\
\hline Usefulness & 694 & 800 & $86,7 \%$ \\
Easy of Use & 945 & 1.100 & $85,9 \%$ \\
Easy of & 345 & 400 & $86,2 \%$ \\
Learning & 602 & 700 & $86 \%$ \\
Satisfaction & $\mathbf{2 . 5 8 6}$ & $\mathbf{3 . 0 0 0}$ & $\mathbf{8 6 , 2 \%}$ \\
\hline Total & & &
\end{tabular}

The results of measurements on the usefullness aspect obtained a percentage of $86.7 \%$ then the conclusion obtained that the e-order system of café 50/50 Coffee menu is very useful. The results of measuring easy of use aspects obtained a percentage of $85.9 \%$ then the conclusion obtained that the e-order system of café 50/50 Coffee menu is very easy to use. The results of the measurement of easy of learning aspects obtained a percentage of $86.2 \%$ then the conclusion obtained that the e-order system of café 50/50 Coffee menu is very easy to learn. The results of measurements in the satisfaction aspect obtained a percentage of $86 \%$ then the conclusion obtained that the e-order system of café 50/50 Coffee menu is very satisfying for users.

The score observed from the total score of answers came from 20 respondents, which was 2,568 , while the expected score was 3,000 . Based on these results, it was obtained a measurement of $86.2 \%$ which in table 3 is at intervals of $81-100 \%$ so that the results of measuring the usability of the Café 50/50 Coffee menu e-order system are classified "Very Useful".

\section{CONCLUSIONS AND SUGGESTIONS}

\section{Conclusion}

Café 50/50 Coffee menu e-order system designed with Waterfall method and uses PIECES method for user satisfaction level analysis. Based on the results of the analysis of the calculation of the average amount of satisfaction level of 4.39, it can be concluded that users of the e-order menu system at Café 50/50 Coffee are Satisfied. While the results of usability measurement of $86.2 \%$ which shows that the e-order system of Café 50/50 Coffee menu is classified as Very Useful.

\section{Suggestion}

Based on the conclusions obtained, there are several suggestions that can later be done for future research that researchers can add other features in the e-order menu system, such as installing payment gateways for payment processes. Further research can also add and develop analytical and testing methods with other methods.

\section{REFERENCES}

Bastian, R. A. (2020). Perancangan Aplikasi Pemesanan Makanan Dan Minuman Pada Cafe Ungu Berbasis Web Pada Jaringan Intranet. Universitas Islam Sultan Agung Semarang.

Dhiman, K. (2021). Online Food Ordering Management System. International Journal for 
Research in Applied Science and Engineering Technology, 9(VII), 2096-2107. https://doi.org/10.22214/ijraset.2021.3683 5

Dzulfiqar, M. A. A. (2019). Sistem Informasi Pemesanan Makanan Berbasis Android Dengan Teknologi Webview Di Warung Makan $\mathrm{Bu}$ Sri. Universitas Duta Bangsa.

Fonggo, F., Beng, J. T., \& Arisandi, D. (2020). Webbased Canteen Payment and Ordering System. IOP Conference Series: Materials Science and Engineering, 1007(1). IOP Publishing Ltd. https://doi.org/10.1088/1757899X/1007/1/012159

Julian, B., Triayudi, A., \& Benrahman. (2021). User Satisfaction Analysis for Event Management Systems Using RAD and PIECES Framework. IOP Conference Series: Materials Science and Engineering, 1088(1), 012024. https://doi.org/10.1088/1757899x/1088/1/012024

Manikam, R. M., \& Ardiyansah, M. (2019). Prototype E-Order pada Restoran Bebek Goreng Haji Yogi Menggunakan Metode PIECES. Jurnal Ilmiah FIFO, 11(2), 189. https://doi.org/10.22441/fifo.2019.v11i2.00 8

Marudut, V., \& Siregar, M. (2018). Perancangan Website Sebagai Media Promosi Dan Penjualan Produk. Technology Acceptance Model, 9(1), 15-21.

Muhammad Robith Adani. (2020, December). Tahapan Pengembangan Perangkat Lunak dengan Metode Waterfall.

Rahayu, T. K., Susanto, \& Suwarjono. (2020). Application Report Process of Islamic School Based on Pesantren Boarding Using Waterfall Model. Journal of Physics: Conference Series, 1569(2). IOP Publishing Ltd. https://doi.org/10.1088/17426596/1569/2/022025

Ramadhani, S., \& Kusuma, W. A. (2018). PIECES Framework untuk Analisa Tingkat Kepuasan Pengguna dan Kepentingan Sistem Informasi. In Jurnal Teknologi \& Manajemen Informatika
(Vol. 4).

Retnoningsih, E., \& Fauziah, N. F. (2019). Usability Testing Aplikasi Rekomendasi Objek Wisata Di Provinsi Jawa Barat Berbasis Android Menggunakan USE Questionnaire. BINA INSANI ICT JOURNAL, 6(2), 205-216.

Riswanda, D., \& Priandika, A. T. (2021). Analisis Dan Perancangan Sistem Informasi Manajemen Pemesanan Barang Berbasis Online. Jurnal Informatika Dan Rekayasa Perangkat Lunak (JATIKA), 2(1), 94-101.

Salwa Husna, S., Fadli, M., \& Hajar, D. (2018). Rancang Bangun Sistem Pemesanan Tiket Bus Berbasis Mobile pada Perusahaan Otobus di Dumai. JURNAL RESTI (Rekayasa Sistem Dan Teknologi Informasi), 2(3), 611-620.

Setiyani, L., Syamsudin, A., Gintings, A., \& Arifin, D. (2020). The Analysis of Functional Needs on Undergraduate Thesis Information System Management. International Journal of Advances in Data and Information Systems, 1(2). https://doi.org/10.25008/ijadis.v1i2.184

Suherman, A., Tetep, T., Mulyana, E., Supriyatna, A., Widyanti, T., Saripah, O., ... Purnawati, L. (2021). Persepsi Masyarakat Terhadap Pemberlakuan Social Distancing Di Masa Pandemi Covid-19 Sebagai Implementasi Modal Sosial. Business Innovation and Entrepreneurship Journal, 3(02), 135-140. https://doi.org/10.35899/biej.v3i02.218

Tjiptabudi, F. M. H. (2017). Analisis Dan Perancangan E-Business Berbasis Website Menggunakan Pieces Framework (Studi Kasus: Aspin Photography \& Video Pro). JURNAL HOAQ - TEKNOLOGI INFORMASI, 8(1), 603-679.

Triayudi, A., \& Rodhi, A. S. (2018). WATERFALL MODELLING PADA SISTEM E-RESTORANT. Jurnal ProTekInfo, 5, 2406-7741. 